\title{
BÚCSÚ A KÖZÉRDEKTŐL?
}

Tóth Judit ${ }^{1}$

2005 márciusában a The New York Times a négy évtizedig létező The Public Interest ${ }^{2}$ folyóirat megszünését siratta. ${ }^{3}$ Bár a lap legfeljebb tízezres előfizetői táborral rendelkezett, mégis az egyik legbefolyásosabb volt a belpolitikában. Eredetileg az alapítók a Konszenzus nevet akarták neki adni, mert úgy vélték, hogy a 30-es évek politikai polarizáltsága a hatvanas évekre megszünt, az új kormányzat, Johnson elnök vezetésével, felszámolja a szegénységet, a negatív jövedelemadó esélyt ad a dolgozó szegényeknek, a feketék beilleszkednek és a migránsok is élvezhetik a friss polgárjogi törvény áldásait. Ám az út göröngyös volt, az évtized végére már a jóléti rendszer válságáról írtak, majd a lapot neokonzervatívnak minősítették, amely a polgárok felelősségét és munkához való viszonyát firtatta. A küldetését mégis teljesítette, miszerint „mindenkinek segítenie kell a közpolitika megvitatásában, hogy egy kicsivel többet tudjunk, mi folyik itt, és föleg arról, miként lehet még hatékonyabban időben cselekedni”. Amerikában legalább létezett egy negyven évig élö, színvonalas újság, ahol valójában arról folyt az intellektuális diskurzus, hogy milyen amerikainak lenni. Nálunk ez a lap meg sem születhetett, mert arról, hogy mi a közjó, közmorál, közérdek minimuma, nincs közmegegyezés évtizedek óta. Sőt ma a nívós társadalmi folyóiratok egy részétől búcsút vehetünk ${ }^{4}$, hiába a tiltakozás, ez partikuláris probléma maradt. A Jogtudományi Közlöny is Vörös Imre főszerkesztő erőfeszítései ellenére is új kiadót keres...

Az MTA jogi bizottsága - szakítva a korábbi testület-csökkentő elvekkel - egyre újabb és újabb albizottságok alakulásának enged utat, talán mert ez a tudomány szabad fejlődésének azaz a köznek is egy kicsit érdeke. Így nem csak a rendészettudományi, de legújabban a börtönügyi és a közjogi albizottság is létrejöhetett. A születést 2016. április 27-én egy szakmai vitával ünnepeltük meg, zeneszó és koccintás nélkül, az MTA titkárságának puritán tárgyalójában. Szigeti Péter professzor nagy ívü összegzése a közérdek fogalmi magyarázatát keresve azonnal jelezte, hogy nincs egységes kiindulópont és magyarázat az elméletben, hiszen az egyéni akaratból csak az emberi társulásokon átszürve válik általános akarattá. Rousseau tehát a közakarathoz ezen áttételeken keresztül jut el, míg Hegel az erkölcsiséget tekinti kiindulásnak, amelynek mint egyéni önfeláldozásnak a napi színtere a család., és a polgári társadalmon át jut el az államhoz, mint erkölcsi és intézményi integráló formához. Ám R. Pound az érdekek harcának látja a társadalmat, amelyben az érdekeken alapul a szerveződés, és végső soron a jog autoritásán és a közösség döntését át juthatunk el addig, hogy a közjavak mindenkinek elérhetőek legyenek, senki se legyen attól megfosztva és persze ne legyenek a rendszerben potyautasok. Bármilyen magyarázatot is fogadunk el, akkor sem lehet hézagmentesen definiálni a közérdeket, de a most folyó kutatása persze új interpretációt hozhat elö.

\footnotetext{
${ }^{1}$ Tóth Judit CSc., tszv. egyetemi docens, SZTE ÁJK.

${ }^{2}$ National Affairs, Public Interest Archive.

3 BROOKS, David: 40 Years of Character, New York Times. March 5, 2005.

${ }^{4}$ Nagy múltú folyóiratok tünhetnek el, Szeged.hu.
} 
Magam is azt tartom, hogy lényegesebb azzal foglalkozni, hogy ki határozhatja meg a közérdeket, továbbá milyen a közérdek felépitése, szerkezete, ha lényegében definiálhatatlan. Egy korábbi közérdek-térképezési kísérletben ${ }^{5}$ részt vettem, amikor próbáltunk túllépni azon a tankönyvi tételen, hogy a közhatalom, és azon belül kifejezetten a közigazgatás a közérdek kielégítését végzi jogalkalmazó és szervező tevékenysége révén, ahogyan azt a törvényhozás és a rendeletalkotás meghatározza számára, mivel az alapja a választásokon győztes párt programjában szereplő prioritások kormányprogramba átültetett és jogi normákban testet öltő közérdek. Ugyanis az alkotmányosság és a piacgazdaság követelményei nem engedik, hogy a magánszférába beavatkozás alapideológiája maradjon a közérdek, ahogy az államszocializmus évtizedeiben. Már Bibó István a magyar közigazgatásról írva kiemelte, hogy a közigazgatás közérdeket szolgáló elvárása egészen másmilyen, ha azt a hatalom, a hivatal vagy a társadalom felöl nézzük. A hagyományos közérdek kontra magánérdek, illetve a joghoz kötöttség kontra hatékonyság vita önmagában terméketlen, mert ez a három szereplő más-más logikát követ: a hatalom hatékony akaratérvényesítést vár, a közigazgatás a szakmai és jogi alapozást, az emberek pedig a szabadságjogaikat, egyéni érdekeiket szeretnék konkrét ügyekben és igen változékonyan számon kérni a közhatalomtól. A közérdek tehát inkább viszony ezen három szereplő között, ezért is definiálhatatlan egyszer s mindenkorra, és a jó közigazgatás ezt a viszonyfogalmat kellő arányokkal tudja szolgálni. Így a kutatás célja az volt, hogy feltárja, vajon mit tehet a közigazgatás a közérdek érvényesítése érdekében.

A vizsgálódás közben kellett rájönni, hogy egyrészt nincs ideológiamentes közérdek, csak a politikai természetű közérdek egy plurális társadalomban, jogállami keretek között, éppen a részleges érvényesülés ellensúlyozására, korrigálható. Másfelől a (rendeleti, törvényi) jogalkotás nem konkretizálja kellőképpen, hogy egyes területeken mi a közérdek, hiába szerepel ma legalább ötven országos jogszabály címében és szövegszerüen legalább kétszáz jogszabályban, közjogi szervezetszabályozó eszközben a közérdek kifejezés. Ezért a közigazgatási hatóságok, a bíróságok, önkormányzatok szabadon mérlegelnek a közérdek értelmezését illetően. Az Alkotmánybíróság elvi jellegű döntéseiben és azok indoklásában az alkotmányos jogok és elvek adott ügyben való prioritásainak megállapításával hoz döntéseket, de nagy mértékben támaszkodik a tételes jogra, és a közérdeket gyakran alapjog korlátozására alkalmas klauzulaként alkalmazza, azaz nem csak alapjogok ütközésekor. Az Európai Unió Bírósága ugyancsak adott ügyekben konkretizálódó, egy tagállam és a közösség konkuráló érdekei, jogelvei és prioritásai alapján hoz döntéseket. ${ }^{6}$

Amire akkor jutottunk, hogy az elmélet nem nyújt kellő táppontot a közérdek általános megfogalmazásához, ezért néhány elv követése a célravezető. Például bizonyosan közérdek: a társadalom rendjének, biztonságának, a jövő generációk létfeltételeinek biztosítása, a jogbiztonságon keresztül - a társadalom békéjének megóvása. Ezek lényegében alkotmányos értékek, amelyek azonban csak eljárási garanciákon keresztül képesek érvényesülni, mégpedig az Alkotmányban, és alacsonyabb szintü jogszabályokban is megfogalmazódva (generálklauzulával, példálózó magyarázatokkal, negatív meghatározásokkal, kizáró szabályokkal), az egyes eljárásokban, mégpedig konkuráló közérdekként megjelenítve. Igaz,

\footnotetext{
${ }_{6}^{5}$ SzAmel Katalin: Közérdek és közigazgatás. Public Interest and Public Administration. Project Report. OTKA.

${ }^{6}$ Judge-Made Public Interest Grounds, Public Interest in UK Courts.
} 
ehhez erős - és nem költségvetéssel, átszervezéssel, létszámstoppal legyengített - jogvédő intézmények ${ }^{7}$ kellenek, sajátos perlési módok, alapjogi jogorvoslati utak.

A közérdek funkcióját illetően, a fentiekből levezetve arra juthatunk, hogy a közéletben és a közbeszédben a politikai döntések, cselekvések igazolására szolgál. Egy demokratikus rendszerben a politikai többség az akaratát a közérdekre hivatkozva formálja át kormányzati akarattá. Másfelől, a közjószágok (például a fenntartható fejlődés, a nemzeti vagyon, a közbiztonság, a köznyugalom, a közmorál) védelmére hivatott, az arányosság és számos processzuális biztosíték alkalmazásával. Ám a politikai és társadalmi funkciókon túl jogi szerepe a közhatalmi szervek előtt különböző, például az Alkotmánybíróság az alapjogokkal összefüggésben értelmezte a közérdeket, és 1990-2010 között az alapjogok legitim korlátozásának lehetőségeként, az egyéni jogok korlátjaként kezelte. Ma az Alaptörvényben csak egyetlen helyen ${ }^{8}$ találkozunk a közérdekkel a kisajátítás jogcímeként, tehát a magántulajdon elvonásának, azaz lényeges tartalmának jogalapjaként, de a társadalmi felelősségre hivatkozás is jelentős alapjog-korlátozást eredményezhet. Ugyanakkor az alapjogi szükségesség-arányosság tesztje kibővült, mert nem csak alapjogok ütközhetnek egymással, hanem alkotmányos értékek is ${ }^{9}$, amelyek pusztán jogalkalmazási úton - és elméleti úton - definiálhatók, jogalkotással aligha. A közérdek máshol a kommunitárius elveket érvényesítve, azaz közvetetten ${ }^{10}$ jönnek elő, vagy valamilyen közéleti részvételt segítve, jogosultságként (közérdekü adatok megismerése ${ }^{11}$, de nem visszaélésszerüen gyakorolva ezt az alapjogot). Így tehát joga lesz az Alkotmánybíróságnak, hogy valamely jogszabály közérdeküségét, annak alaptörvényi összefüggését vagy közvetlenül a közérdek fogalmát kifejtsék, definiálják. Mivel 2010-2012 között a testület az Eötvös Károly Közpolitikai Intézet elemzése ${ }^{12}$ szerint $77 \%$-ban a kormány álláspontját, szándékait tette magáévá határozataiban, e trend megváltozására alappal nem számíthatunk. ${ }^{13}$. Balázs Zoltán kutatása ${ }^{14}$ jelzi, hogy az alkotmánybíráskodást áthatják a politikai állásfoglalások, és az alaptörvényt is egészében véve a közérdek megfogalmazásának, illetve a jog és a politika közti kapcsoló elvnek tekintik a bírák, más helyen pedig a konkrét közérdek definiálást a bíróságokra hagyják (pl. az emberi méltóság határainak meghúzásában a közéleti szereplők védelmében), míg máshol elfogadják a jogalkotói és igazgatási intézményi korlátokat (pl. versenyhivatal, élelmiszer-biztonság).

Vegyünk búcsút a közérdektől tehát abban az értelemben, hogy rétegzettsége (helyi, nemzeti, tagállami, európai, globális), interdiszciplinaritása és konkrét megnyilvánulásának konkurráló jellege kizárja az egyetlen, időtálló, korokon átívelő definiálást. Ez azonban nem a vizsgálódás és főleg nem a közjogot folytonosan mozgató közérdek temetése, hanem a kutatói érdeklődés, a jogvédői tiltakozás feltámadását hozza el.

\footnotetext{
${ }^{7}$ PONGÓ Tamás - SzAKÁLy Zsuzsa (szerk.): Jogvédelmi kaleidoszkóp: a jogvédelem elmúlt öt éve (2009-2014) Magyarországon, Pólay Elemér Alapítvány, Szeged, 2015. 9-22.

${ }^{8}$ Alaptörvény, XIII. cikk.

${ }^{9}$ Alaptörvény, I. cikk, 3. bek.

${ }^{10}$ Alaptörvény, O. cikk és R. cikk, 3 bek.

${ }^{11}$ Alaptörvény, VI. cikk.

${ }^{12}$ UNYATYINSZKI György: Egyértelmü, a kormánynak kedvez az Alkotmánybíróság. Hvg.hu, 2015.

${ }^{13}$ SÓLYOM Péter: Jogállam szódával. Közjavak.hu, 2016.

${ }^{14}$ BALÁZS Zoltán: A közérdek az alkotmánybíráskodásban (2012-2014).
} 